\title{
804 熱化学法水素製造装置のための設計・解析支援システム
}

CAE System for Designing Thermo-Chemical Hydrogen Production Plant

○ 寺田敦彦（原研）、正.日野竜太郎（原研）

Atsuhiko TERADA and Ryutaro HINO

Japan Atomic Energy Research Institute

Narita-cho Niibori 3607, Oarai-machi, Higashi ibaraki-gun, Ibaraki-ken 311-1394

In the Japan Atomic Energy Research Institute, a pilot test plant of $30 \mathrm{Nm} 3 / \mathrm{hr}-\mathrm{scale}$ hydrogen production by using thermo chemical water splitting process with iodine and sulfur (IS process) is been planning to establish nuclear heat utilization technology of high-temperature gas-cooled reactors. To promote design works of the pilot test plant, we have started to construct a CAE system to estimate and optimize heat-mass balance of the IS process, thermo-mechanical and thermal-hydraulic performances of chemical reactors process, safety system etc. This report presents an outline of the CAE system.

Key Words: Hydrogen production, CAE, Thermo-mechanical, Thermal-hydraulic, Safety system,

\section{1.はじめに}

日本原子力研究所（原研）では、高温ガス炉技術と 核熱利用技術の確立を目指して、水素製造システムと 高温工学試験研究炉 (HTTR) の接続を計画している。 これは、 $950^{\circ} \mathrm{C}$ の高温の熱を炬外に取り出すことがで きる高温ガス炬の特徵を生かし、将来の水素利用社会 の実現に向けて、環境保全性に優れかつ経済性の高い 水素製造技術の実現を目指す試みである。原研では、 将来の大量水素需要に対応した幾つかの水素製造技 術のうち、核熱を利用して水を熱分解するISプロセス 熱化学法の開発研究を進めてきた(1).ISプロセスは、 $900^{\circ} \mathrm{C}$ 程度までの熱を利用してヨウ素 $(\mathrm{I})$ と硫黄 (S) を循環させて水を熱分解して水素を製造する手法で、 全体の反応は以下のように表される。

\section{・ブンゼン反応 :}

$\mathrm{I}_{2}(\mathrm{~L})+\mathrm{SO}_{2}(\mathrm{G})+2 \mathrm{H}_{2} \mathrm{O}(\mathrm{L}) \rightarrow 2 \mathrm{HI}(\mathrm{L})+\mathrm{H}_{2} \mathrm{SO}_{4}(\mathrm{~L})$

- ヨウ化水素分解反応 :

$$
2 \mathrm{HI}(\mathrm{G}) \rightarrow \mathrm{H}_{2}(\mathrm{G})+\mathrm{I}_{2}(\mathrm{G})
$$

- 硫酸分解反応 :

$$
\mathrm{H}_{2} \mathrm{SO}_{4}(\mathrm{~L}) \rightarrow \mathrm{H}_{2} \mathrm{O}(\mathrm{L})+\mathrm{SO}_{2}(\mathrm{G})+0.5 \mathrm{O}_{2}(\mathrm{G})
$$

これまで原研では、1997年に実験室規模でISプロセ スの水素製造理論を世界で初めて検証した。さらに、 第 2 段階である工学基礎試験装置で毎時 35 リットル、 6.5 時間の連続水素製造運転に2003年8月世界で初め て成功した。2004年度まで特性試験、制御試験、長時 間連続試験等を行う予定である(2)。今後は、技術的成 立性を確認するため及び実用化に向けた経済性評価 に必要なデータを収集するための第 3 段階の $30 \mathrm{~m}^{3} / \mathrm{h}$ 規模のパイロット試験、最終段階としてISプロセスを 原子炉に接続し、高温ガス炉水素製造システムを実証 する $1000 \mathrm{~m}^{3} / \mathrm{h}$ 規模のHTTR接続試験へとスケールア ップして、実用化につなげることを目指している。

ISプロセスの基本構成をFig.1に示す。ブンゼン反 応器を中心にして、三相分離器、分解器、蒸留塔等の
プロセス機器の設計開発においては、硫酸、ヨウ化水 素系の過酷な腐食環境下で使用する耐食、耐熱材料の 開発評価やプロセス全系の熱効率の向上等、幾つかの 技術的な課題がある。これらの課題への対応と設計業 務の効率化を図るには、プロセス特性（制御）、材料 評価と、これに基づくプロセス機器の構造強度・熱流 動特性評価およびプラント安全評価を系統的にすす める解析コード体系の整備が不可久である。

本報は、ISプロセスの設計開発にあたって、解析的 に評価が必要な技術課題への対応を図るために整備 した解析コード体亲を紹介する。

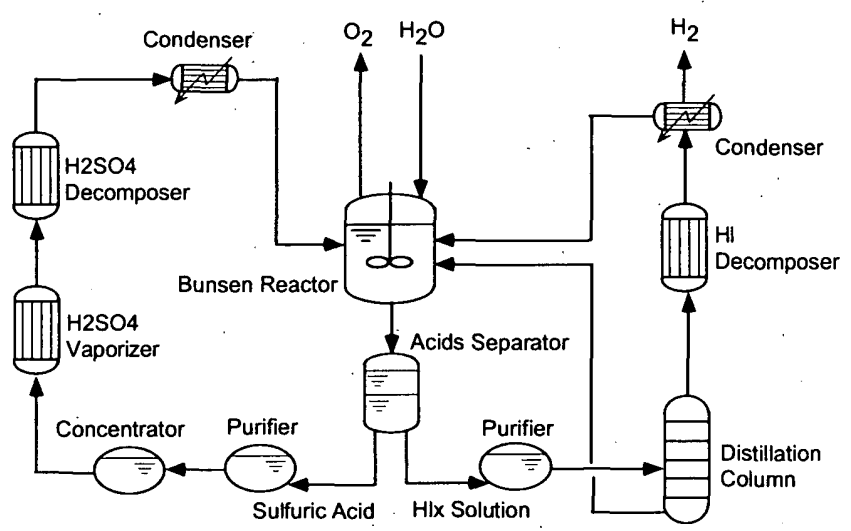

Fig.1 Schematic diagram of IS process

\section{2. 設計・解析支援システム体系の概要}

IS プラントの設計開発に関する設計フローを·Fig.2 に示 す。以下に現在、調整を進めているコード体系について、 主要項目の概要を記す。

（1）プロセス特性評価によるシステム設計

IS プロセスは、主要な 3 つの化学反応を協調させて連続 的に動作させるための閉サイグルシステムから構成されれて 
いる。システムは熱効率的な最適化を図り、機器の仕様や 配置、定格運転条件を決定する。さらに、プラントの運転 制御手法を確立する必要がある。これには、原研にて蓄積 してきた多種にわたるデータに基いた物性推算式の構築が 可能なこと、また IS プロセス特有な反応モデルの構筑が容 易であること等の要件を満足する「ProII」等のシミュレー タを採用する。

\section{（2）材料評価}

IS プロセスの 3 つ主要な反応系は、それぞれ極めて過 酷な腐食環境である。一方、IS プロセスの実用化には、高 圧ガス保安法などに規定される圧力容器の安全基準にとど まらず、隣接する高温ガス炬も含めた安全設計なども求め られる可能性が高い。このため、用いられる材料は耐食性 にとどまらず、クリープ、疲労、SCC などの信頼性に関わ る特性にも十分留意して選定される必要がある。さらに、 競合する他の水素製造プロセスに対してコスト、環境負荷 の面でも競争力を有する材料でなければならない。したが って、システムの基盤となる構造用材料にあたっては、腐 食試験等の実験データに基づく耐食材料データベースと反 応生成物の熱物性データベースの整備を進めている。一方、 並行して腐食・防食シミュレータ「CSP+OLI」を導入し、 腐食速度等の挙動を解析的な評価を行う。

\section{（3）構造・熱流動}

IS プロセスの設計開発では、過酷な腐食環境下で使用す る分離、精製、蒸留、反応器等の多種多様な耐圧・耐食容 器を開発する必要がある。機器の基本構造は、反応率や熱 交換率等の性能向上を図るために熱流動の観点から最適な 形状を選定し、これに耐压性と腐食代を考慮した材料と板 厚等を選定する。容器内の熱流動特性を把握するには、複 雑な乱流混合の数值解析に対応した数種の 2 方程式乱流モ デルと応力方程式モデルを扱うことが可能な「STAR·CD」、

〔FLUENT」等に加え、混相流、他成分反応流を考虑した コードの開発を行う。設計・開発に使用するコードは、時 系列 PIV/PLIF システムを用いた可視化試験等により検証 する計画である。また、構造材の強度評価については、選 定が有力視されているガラス、 $\mathrm{SiC}$ 等の非金属や耐食材をラ イニングした複合材の評価方法を検討する必要があるが、

「ABAQUS」にて対応する。構造検討に関する最適化のプ ロセスは、CAD との連携による効率化を図る。

(4) 安全評価

原子力水素製造システムでは、HTTR に水素製造プラン 卜を接続し、多量の可燃性物質を扱うことになる。これに 起因する火災、爆発事故に対して原子炬の安全性を確保す ることが大きな課題であるが、明確な安全基準が定められ ていない。したがって、IS 水素製造プラントにおける爆発・ 火災事故がどの程度 HTTR 施設へ影響を及ぼすかを解析評 価し、安全性評価を行う必要がある。安全評価システムは、 (1)火災・爆発事故の影響評価を行うコードシステムおよび データベース，(2)IS プラントのプロセス特性コードと
HTTR プラント動特性解析コードの連成機能において構成 を検討する。IS プロセスの異常に対する原子炬応答解析で は、我が国初となる原子炉系/熱利用系との接続を考慮した 安全審查に対応するため、様々な事象を想定した相当量の 動特性評価が課されることが予想される。このため、原子 炉/水素製造システム全体の熱流力特性を合理的に評価する ため、原子炉側の動特性解析コード（RELAP-5/ConanGTHTR/ACCORD 等）とのインターフェースを整備する。

\section{3、あとがき}

IS プラント開発・設計に関して、解析的に評価が必要な 技術課題に対応する解析コード体系について全体像を検討 し、Fig.3にまとめた。今後、本解析・支援システムを導入・ 構築し、開発環境の整備を図ることにより、IS プラントの 設計開発を効率的に推進するとともに、解析コードの有効 性を確認するR＆Dを実施する計画である。

参考文献

(1) K.Onuki, et.al: IS Process for thermo-chemical hydrogen production, JAERI-Review 94-006 (1994).

(2) S.Kubo, et.al: R\&D on water spilitting IS process for hydrogen production using HTGR at JAERI, AIChE 2004 Spring National Meeting, New Orleans, USA, April 25-29 (2004).

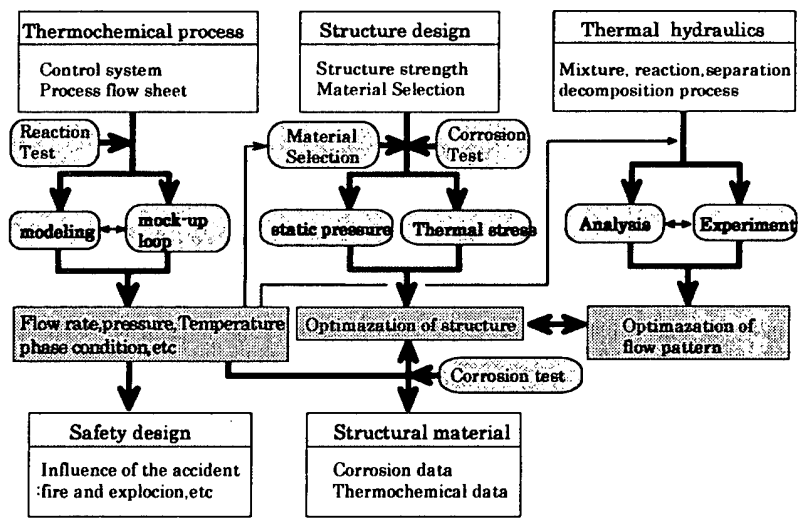

Fig.2 Scematic diagram of IS process design

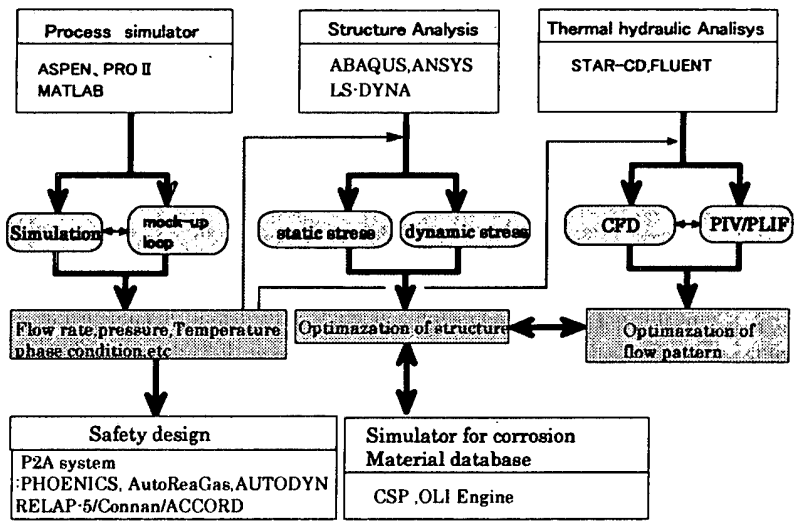

Fig.3 CAE system for IS process design 